
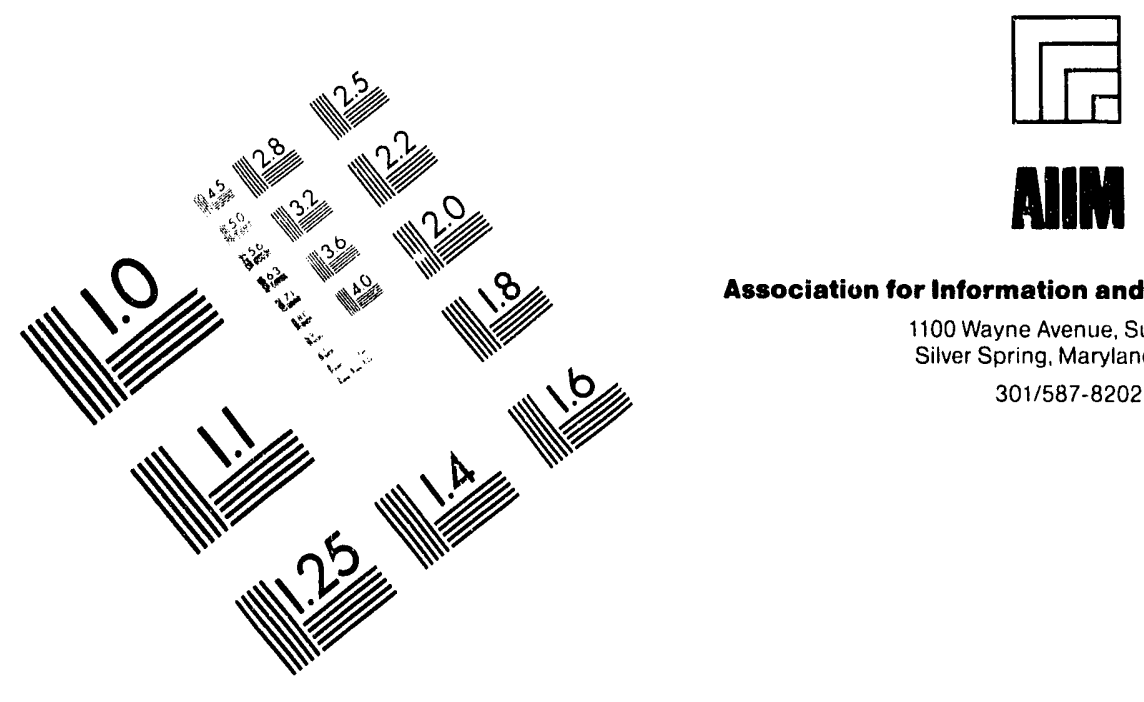

Association for Information and Image Management

1100 Wayne Avenue, Suite 1100

Silver Spring. Maryland 20910

301/587-8202

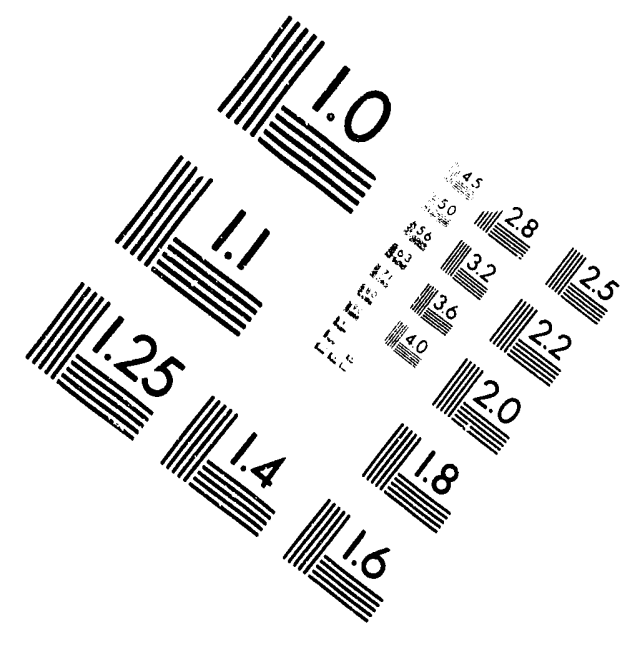

\title{
Centimeter
}

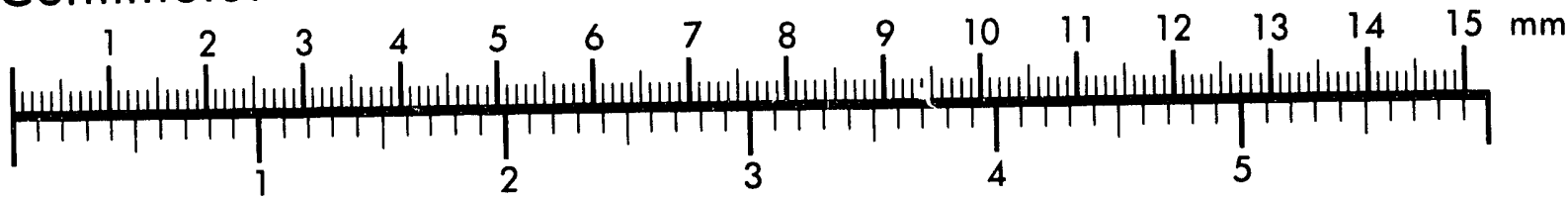

Inches
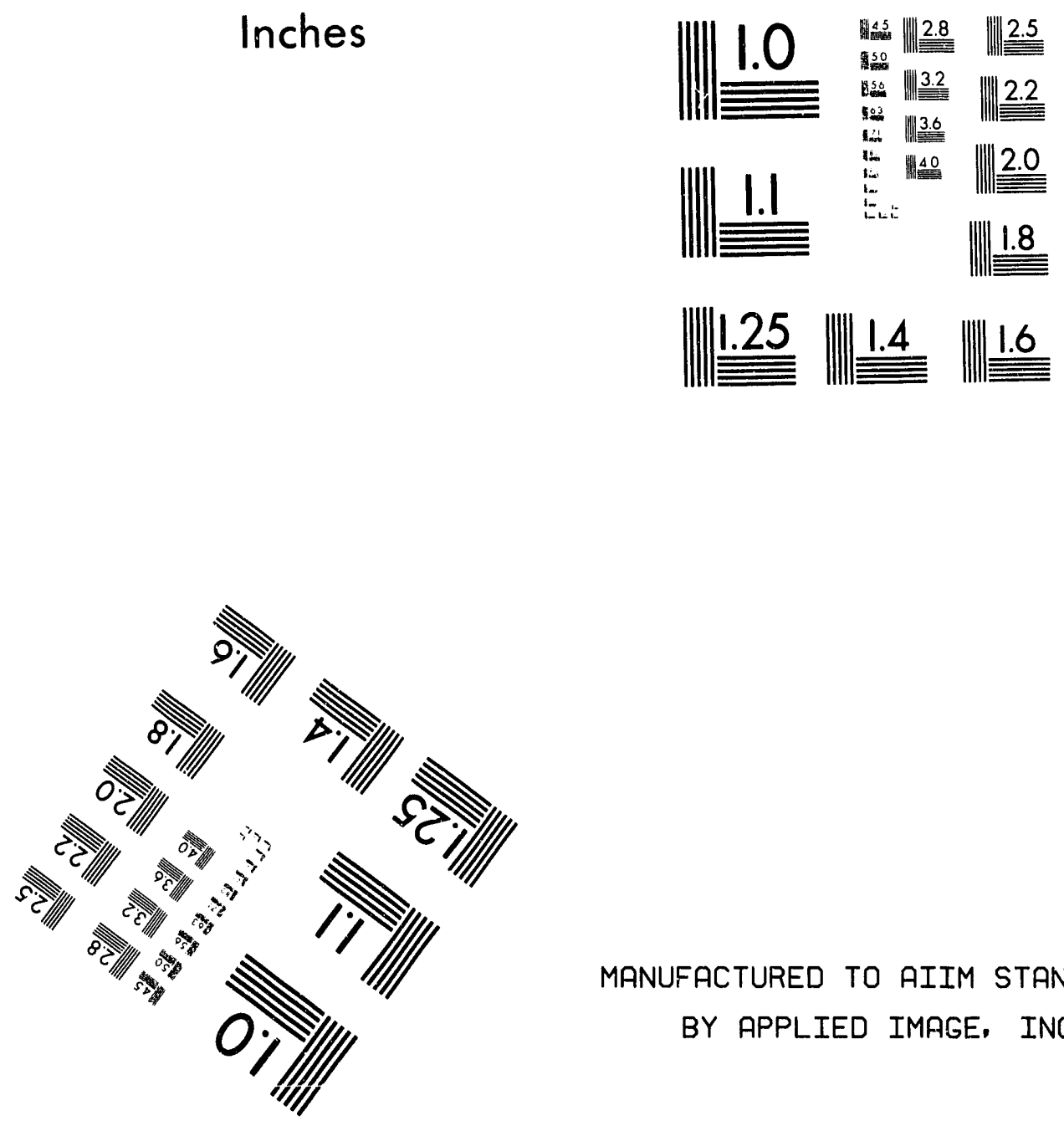

MANUFACTURED TO AIIM STANDARDS

BY APPLIED IMAGE, INC.

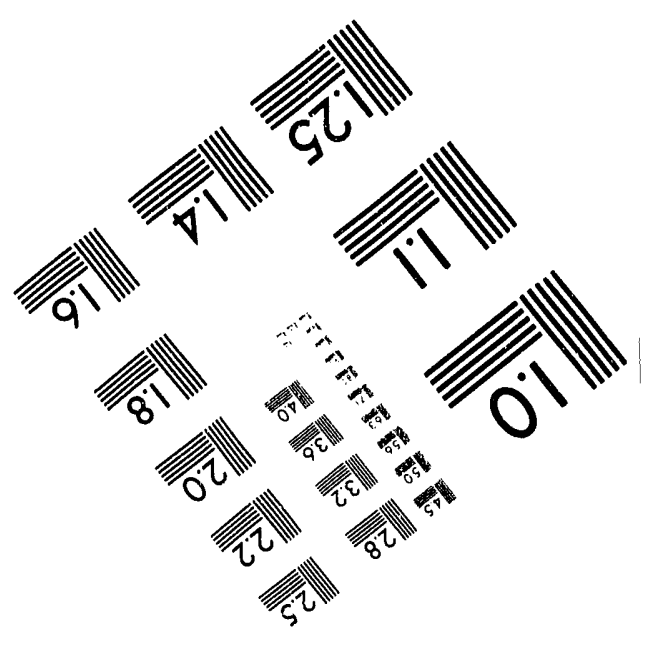



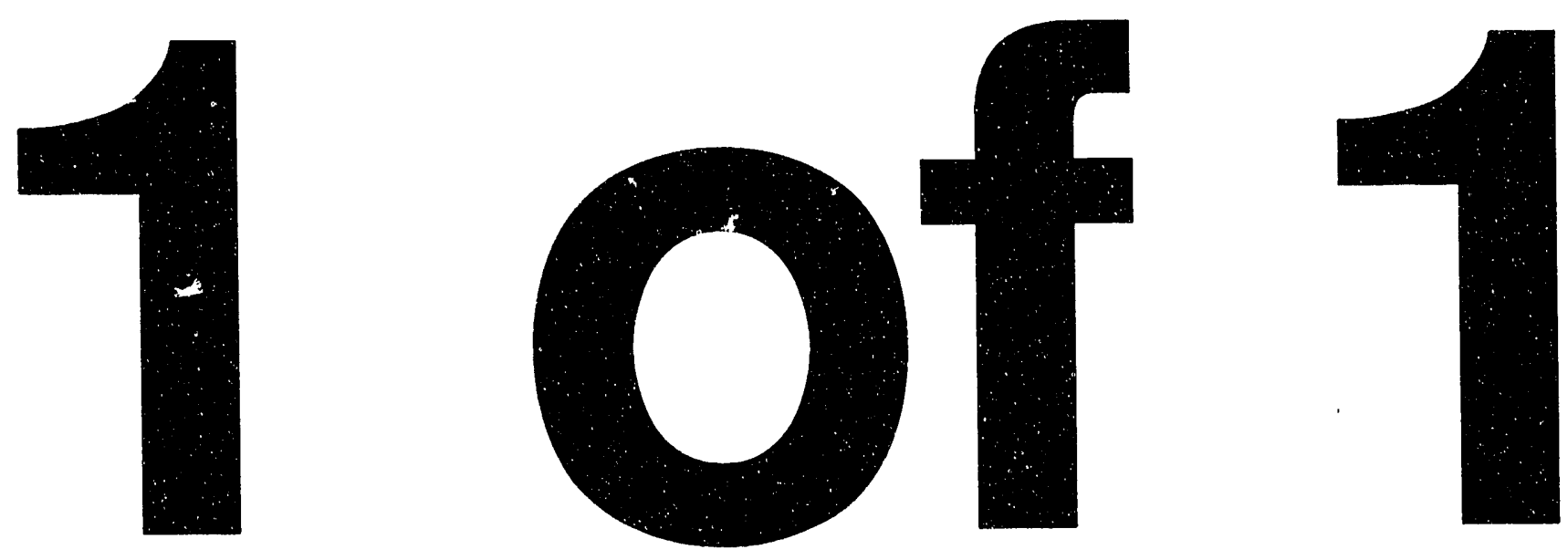


\title{
DOE/ER/61014-3
}

\section{THE ROLE OF CLOUDS AND OCEANS IN GLOBAL GREENHOUSE WARMING Report No. DOE/ER/61014-3}

\author{
PART I--PROGRESS REPORT \\ DOE Grant No. DE-FG02-90ER61014 \\ PRINCIPAL INVESTIGATOR \\ Martin I. Hoffert
}

\author{
Submitted to the DEPARTMENT OF ENERGY \\ December 1992
}

\section{DISCLAIMER}

This report was prepared as an account of work sponsored by an agency of the United States Government. Neither the United States Gnvernment nor any agency thereof, nor any of their employees, makes any warranty, express or implied, or assumes any legal liability or responsibility for the accuracy, completeness, or usefulness of any information, apparatus, product, or process disclosed, or represents that its use would not infringe privately owned rights. Reference herein to any specific commercial product, process, or service by trade name, trademark, manufacturer, or otherwise does not necessarily constitute or imply its endorsement, recommendation, or favoring by the United States Government or any agency thereof. The views and opinions of authors expressed herein do not necessarily state or reflect those of the United States Government or any agency thereof.

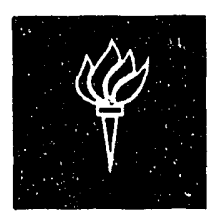

NEW YORK UNIVERSITY

Faculty of Arts and Science

DEPARTMENT OF APPLIED SCIENCE

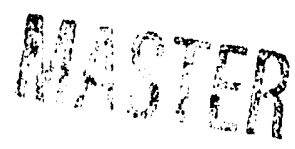




\title{
THE ROLE OF CLOUDS AND OCEANS IN
}

\author{
GLOBAL GREENHOUSE WARMING
}

DOE Grant DEFG02-90ER61014

\section{Part I -PROGRESS REPORT}

by

\section{Martin I. Hoffert, Principal Investigator}

Earth Systems Group, Department of Applied Science, New York University, New York, NY 10003

During the past three years we have conducted several studies using models and a combination of satellite data, in situ meteorological and oceanic data, and paleoclimate reconstructions, under the DoE program, "Quantifying the Link Between Change in Radiative Balance and Atmospheric Temperature" (MacCracken et al., 1989). Our goals were to (1) investigate effects of global cloudiness variations on global climate and their implications for cloud feedback and (2) continue development and application of NYU transient climate/ocean models, with emphasis on coupled effects of greenhouse warming and feedbacks by both the clouds and oceans. Our original research plan emphasized the use of cloud, surface temperature and ocean data sets interpreted by focused climate/ocean models to develop a cloud radiative forcing scenario for the past 100 years and to assess the transient climate response; to narrow key uncertainties in the system; and to identify those aspects of the climate system most likely to be affected by greenhouse warming over short, medium and long time scales.

In the course of our research we discovered many new and interesting things about how clouds, aerosols and oceans feed back on climate cilange. Perhaps our most important finding was a new approach to calibrating the climate sensitivity of the Earth using a combination of models and empirical paleoclimate data. Among other things, our methods provide a path around cloud feedback uncertainties that currently plague global climate models (GCMs). Our preliminary findings are published in the December 10, 1992 issue of Nature (Hoffert and Covey, 1992). Additional background is provided below. Future developments and proposed applications of our approach are discussed in Part I - RESEARCH PROPOSAL. 


\section{Cloud Forcing and Cloud Feedback}

One reason cloud feedback effects are so problematical is that the collective condensation of water vapor to droplets and ice crystals in clouds is influenced by phenomena occurring over a wide range of spatial scales and meteorological conditions. The dependence of cloud formation and cloud radiative interactions on nonlinear and, more importantly, on nonlocal phenomena complicates the parameterization problem enormously. There is also no guarantee that climate models which reproduce the presently observed cloud fraction distributions (FIG. 1) -- most GCMs do this to some extent -- will correctly predict the the altered radiation forcing from cloudiness changes induced by climate changes.

One of our first tasks was to attempt to estimate cloud radiative feedback from empirical data. Because of the difficulty in unambiguously defining the "cloud fraction" (Hahn et al., 1988), and because changes in cloud radiative properties can occur at constant cloud fraction (Somerville and Remer, 1984), we worked with cloud radiative forcing (CRF) -- the net radiative flux per unit surface area of the Earth produced by clouds (Ramanathan et al., 1989).

One approach to utilization of CRF satellite data, such as the International Cloud Climatology Project (ISCCP) and the Earth Radiation Budget Experiment (ERBE), is to develop statistical correlations between cloud types and CRF for use in GCMs (Hartmann et al., 1992). This leaves the open problem of which cloud types form under altered climate conditions. But it is recognized that nonlinear interactions of cloud formation and cloud radiative processes control cloud radiative feedback. Since our study began, DoE initiated the Atmospheric Radiation Measurements (ARM) program at least partly to address uncertainties in how cloudiness changes affect climate changes (Patrinos, 1990). Indeed, the present factor of three uncertainty in the GCM derived climate sensitivity of the Earth -- $\Delta T_{2 x}$ in the range of 1.5 to $4.5 \mathrm{oC} \mathrm{--}$ is directly attributable to uncertainties in cloud radiative feedback (Cess et al., 1989). Even the sign is unknown (FIG. 2).

Because cloud feedback is a nonlocal phenomena -- for example, cloud formation may depend on horizontal gradients, not just surface temperature --- we sought correlations between CRF changes and surface temperature changes during the seasonal cycle for the northern hemisphere (NH) and southern hemisphere $(\mathrm{SH})$ as a whole.

We worked with Ed Harrison of the Radiation Sciences Branch, NASA Langley Research Center to get the latest cloud radiative forcing data 
measured by ERBE satellites. The data were hemispherically and monthly averaged separately for the $\mathrm{NH}$ and $\mathrm{SH}$. All three components, namely long wave, short wave and net cloud radiative forcing for the years 1984 through 1988 were analyzed. Surface air temperatures were also hemispherically and monthly averaged separately for the northern and southern hemisphere were employed from the National Climate Data Center (NOAA) archives for the corresponding years where ERBE data is available. It was necessary among other things to correct for the variation of the solar CRF component due to changing solar forcing incident on a hemisphere during the seasonal cycle. Recognizing that the spatial pattern of seasonal radiative forcing is different than the interannual forcing to be expected from, say, greenhouse gas build up, it was still highly suggestive that we found a small net cloud radiative feedback from this satellite study, of the order of $10 \%$ of the total climate sensitivity.

\section{Paleoretrievals of Climate Sensitivity}

Much of our research has emphasized simple climate/ocean models to understand transient climate response to greenhouse gas build-up on decadal to hundred year time scales (Hoffert 1989a, 1992; Hoffert and Flannery, 1985; Hoffert et al., 1980; 1988). Despite its simplicity compared with full blown GCMs, the upwelling-diffusion ocean climate model of Hoffert et al. (1980) has proven quite useful in estimating future climate changes from the build-up of greenhouse gases in the atmosphere (IPCC, 1990; 1992; Schlesinger and Jiang, 1991; Wigley and Raper, 1992).

The Intergovernmental Panel on Climate Change (IPCC) used the Hoffert et al. transient ocean/climate model to project global warming durizig the next century over the uncertainty range of GCM-derived sensitivities (FIG.

3). Four future radiative forcing scenarios were examined, A, B, C \& D, representing progressively more constrained greenhouse gas emissions. All the scenarios produced some global warming, but unconstrained emissions (Business as Usual, A; "SA90" in IPCC updates) in combination with the weakest climate sensitivity $\Delta \mathrm{T}_{2 \mathrm{x}}=1.5 \mathrm{OC}$ produce about the same warming as the most highly constrained emissions (D) with the strongest climate sensitivity $\Delta \mathrm{T}_{2 \mathrm{x}}=4.5 \mathrm{OC}$. Since the implementation costs of $\mathrm{A}$ and $\mathrm{D}$ are quite different, the climate sensitivity uncertainty, most of which is due to cloud feedback uncertainties, has a major impact on the cost-projections of emission controls.

Attempts to derive global climate sensitivity by matching a transient climate/ocean model to the hundred year temperature record forced by 
anthropogenic greenhouse gases have been equivocal because of uncertainties in compensatory sulfate aerosol forcing (Wigley, 1989; Wigley and Raper, 1992; Schlesinger et al., 1992). Our initial conclusions (Hoffert et al., 1988) that solar variability effects on historical and future global temperature changes are small has stood the test of time (Schlesinger and Ramankutty, 1992; Kelly and Wigley, 1992) despite a remarkably suggestive correlation of surface temperature changes with solar cycle length (Friis-Christensen and Lassen, 1991).

"Anti-greenhouse" cooling from increased solar radiation scattered back to space by humanity's sulfate aerosols cancelling part of humanity's greenhouse warming is a more serious prospect. Among other things, this hypothesis is consistent with findings that much of the global warming observed over land occurs when the sun is not shining, at night (Karl et al., 1991). The possibility of compensatory aerosol forcing of the same magnitude but opposite sign as greenhouse gas forcing make the estimation of climate sensitivity including cloud feedback effects from historical records and transient climate models problematical. There are too many sources of uncertainty in the forcing, and too much noise in the response.

We felt that a better approach might be to look to prior equilibrium periods in the geological record when forcing and response were less ambiguous. We therefore asked whether, by simultaneously reconstructing the forcing and response of prior climates very different from today, it would be possible to estimate global climate sensitivity as well or better than by GCMs? Since cloud feedback is one of the rapidly-responding feedbacks included in paleo-sensitivity, this technique would yield, as a bonus, the cloud radiative feedback. Note that the clear sky radiative feedback from water vapor, sea ice and snow is well characterized (to within $\pm 10 \%$ ).

Two periods were chosen for our initial paleosensitivity retrievals: (1) the last glacial maximum (LGM) cooling $\sim 21.5$ thousand years before present and (2) the mid Cretaceous maximum warming $(\mathrm{MCM}) \sim 100$ million years ago. TABLE 1 summarizes the forcing, response and climate sensitivity estimated for these two periods. Additional details can be found in Hoffert and Covey (1992). Data from two palaeoclimates, one colder and one warmer than present, yields $\Delta \mathrm{T}_{2 \mathrm{x}}=2.3 \pm 0.9 \mathrm{O} \mathrm{C}$. The mean value is quite close to the $\mathrm{CO}_{2}$ doubling climate sensitivity of the clear sky (with clouds neutral) $\Delta \mathrm{T}_{2 \mathrm{x}}=$ $2.2 \pm 0.2{ }^{\circ} \mathrm{C}$. The implication of Hoffert and Covey (1992) that net cloud radiative feedback is a small component of the total climate sensitivity is quite similar to our finding of small cloud radiative feedback from our ERBE datatemperature correiation over the seasonal cycle. This would be an extremely important if it continues to stand up to scrutiny and additional tests against 
empirical data, so we intend to continue this investigation during our continuation of our "quantitative links" project.

Another finding from our paleoclimate studies was that the "universal" distribution of equator-to-pole temperature changes (normalized by the hemispheric mean temperature change) proposed by USSR researchers (Borzenkova et al., 1992; Budyko and Izrael, 1991; MacCracken et al., 1990) for three paleoclimates also describes the much warmer MCM and much colder LGM (FIG. 4). It is important that Western data sources for different periods support this curve is because there was reluctance on the part of the IPCC to accept the Russian data, perhaps because the paleoclimate transfer functions and data reduction methods were not well-documented in English language publications. If the global climate sensitivity is the zeroth-order quantity predicted by climate models, then equator-to-pole temperature differences can be considered the first order quantities. These too are highly uncertain in climate models. We believe a focussed application of paleoclimate data can illuminate this problem as well. In our research proposal we discuss how progress can be made using newly available paleodata from the former USSR.

\section{Ocean Mixing Feedbacks from Density Stratification}

Our original proposal emphasized the future development of ocean climate models including feedbacks from the changing stratification of the surface ocean. The main variables of our World Ocean model are the horizontally-averaged upwelling velocity $w(z)$ and potential temperature $T(z)$. "Potential" thermodynamic properties are employed to simplify treatment of compressibility effects, and are defined in the usual way as the temperature and density seawater parcels attain on adiabatic expansion to surface pressure (1 atm). The potential density profile $\rho(z)$ controls the internal wave and turbulence structure of the oceans though the buoyancy frequency,

$$
N \equiv \sqrt{-\frac{g}{\rho} \frac{\partial \rho}{\partial z^{\prime}}} \quad(>0 \text { for stable stratification) }
$$

where $-\mathrm{z}$ is the depth. Prior progress reports have documented our new ocean model in which the vertical eddy diffusivity varies inversely with the buoyancy frequency, $\mathrm{k} \sim$ constant/ $\mathrm{N}$. 
FIG. 5 illustrates that our stratified diffusivity model reproduces the potential temperature and potential density of the horizontally-averaged world ocean, if anything, better than the constant-k model. But notice in FIG. 6 that the eddy diffusivity is lowest near the surface and increases with increasing depth. This means that heat entering the deep ocean though the polar sea (that is, heat bypassing the thermocline bottleneck near the surface) can diffuse more rapidly into the ocean, whereas heat entering from the surface is retarded in its diffusive penetration by the increased stratification.

What is the effect of interactive ocean mixing on the transient response of global surface temperature? To answer this we set up our ocean/climate model for both constant and interactive eddy diffusivity, allowed various combinations of high-latitude warming and deep ocean mixing, and radiatively forced the models with the IPCC (1990) greenhouse gas buildup scenario. Results are shown in FIG. 7 along with the instrumental temperature record smoothed by a 5-year running mean. When deep sea ventilation is suppressed, diffusive stratification feedback is positive because the surface attains a greater fraction of its equilibrium warming as less heat penetrates the thermocline. However, when the deep sea communicates and mixes with the high-latitude surface, and when the high latitudes are allowed to warm along with the mean surface ocean, the feedback becomes negative, because more heat enters and mixes to the deep ocean. For the climate sensitivity chosen (calibrated from paleoclimate data), the most realistic results involve a fast track to the deep sea bypassing the main thermocline. Again, these results are potentially quite important, but need to be tested more carefully against radiocarbon and other tracer data for consistency. We hope to do this in our forthcoming studies under this grant. 


\section{BIBLIOGRAPHY}

Barron, E.J., S.L. Thompson and S.H. Schneider (1981) An ice-free Cretaceous? Results from climate model simulations. Science, 212, 501-505.

Barron, E.J. and W.M. Washington (1985) Waim Cretaceous climates: High atmospheric $\mathrm{CO}_{2}$ as a plausible mechanism. In Sundquist, E.T., and W.S. Broecker (Eds.), The Carbon Cycle and Atmospheric $\mathrm{CO}_{2}$ : Natural Variations Archean to Present. Geophys. Mongr. 32, pp. 546-553, American Geophysical Union, Washington, DC.

Berner, R.A., (1990) Atmospheric carbon dioxide over Phanerozoic time. Science, 249, (1990), 1382-1386.

Berner, R.A. (1992) Palaeo- $\mathrm{CO}_{2}$ and climate. Nature, 358, 114.

Borzenkova, I.I., V.A. Zubakov and A.G. Lapenis (1992) Global climate reconstructions of warm past epochs, Meteorologia $i$ Gidrologia, No. 8, 25-37 (in Russian).

Budyko, M.I. and Yu.A. Izrael (1991) Anthropogenic Climate Change, pp. 277318, University of Arizona Press, Tucson.

Budyko, M.I., A.B. Ronov and A.L. Yanshin (1987) History of the Ear' $h$ 's Atmosphere. Springer-Verlag, New York, 139 pp.

Bryan, F. (1987) Parameter sensitivity of primitive equation ocean general circulation models. J. Phys. Oceanogr. 17, 970-985.

Carissimo, B.C., A.H. Oort and T.H. Vonder Haar (1985) Estimating the meridional energy transports in the atmosphere and ocean. J. Phys. Oceanogr. 15, 82-91.

Cess, R.D., G.L. Potter, J.P. Blanchet, G.J. Boer, S.J. Ghan, J.T. Kiehl, H.Le Treut, Z.-X. Li, X.-Z. Liang, J.F.B. Mitchell, J.-J. Morchette, D.A. Randell, M.R. Riches, E. Roeckner, U. Schlese, A. Slingo, K.E. Taylor, W.M. Washington, T.R. Wetherald and I. Yagai (1989) Interpretation of cloud-climate feedback as produced by 14 atmospheric general circulation models. Science, 245, 513-516. 
Chappellaz, J., J.M. Barnola, D. Raynaud, Y.S. Korotkevich and C. Lorius (1990) Ice-core record of atmospheric methane over the past 160,000 years. Nature, 345, 127-131.

Charlson, R.J., J.E. Lovelock, M.O. Andreae and S.G. Warren (1987) Oceanic phytoplankton, atmospheric surphur, cloud albedo and climate. Nature, 326, pp. 655-661.

Charlson, R.J., S.E. Schwartz, J.M. Hales, R.D. Cess, J.A. Coakley, Jr., J.E. Hansen and D.J. Hofmann (1992) Climate forcing by anthropogenic aerosols. Science, 255, 423-430.

Covey, C. (1988) Atmospheric and oceanic heat transport: Simulations versus observations. Climatic Change, 13, 149-159.

Covey, C. and S.L. Thompson (1989) Testing the effects of ocean heat transport on climate. Paleogeography, Paleoclimaology, Paleoecology, 75, 333-341.

Crowley, T.J. and G. North (1991)Paleoclimatology, Oxford University Press, New York.

Dowsett, H.J., T.M. Cronin, R.Z. Poore, R.S. Thompson, R.C. Whatley and A.M. Wood (1992) Micropaleontogical evidence for increased meridional heat transport in the North Atlantic Ocean during the Pliocene. Science, 258, 1133-1135.

Fofonoff, N.P. and F. Webster (1971) Current measurements in the Western Atlantic. Phil. Trans. R. Soc. Lond. A.270, pp. 423-435.

Friis-Christensen, E. and K. Lassen (1991) Length of the solar cycle: An indicator of solar activity closely connected with climate. Science, 254, 698-700.

Gargett, A.E. (1989) Ocean turbulence. Ann. Rev. Fluid Mech., 21, pp. 419-451.

Garrett, C.J.R., Mixing in the ocean interior (1979) Dyn. Atmos. Oceans, 3, 239265.

Garrett, C.J.R. and W.H. Munk (1972) Oceanic mixing by breaking internal waves. Deep-Sen Res., 19, 823-832.

Gaffin, S.R., M.I. Hoffert and T. Volk (1986) Nonlinear coupling between surface temperature and ocean upwelling as an agent in historical climate variations. J. Geophys. Res., 91 (C3), pp. 3944-3950. 
Hahn, C.J., S.G. Warren, J. London and R.L. Jenne (1988) Climatological Data for Clouds over the Globe from Surface Observations. NDP-026, Carbon Dioxide Information Analysis Center (CDIAC), Oak Ridge National Laboratory, Oak Ridge, Tennessee; hard copy text plus CDIAC data package on magnetic tapes for the 11 year period 1971-1981.

Hansen, J., A. Lacis, D. Rind, G. Russell, P. Stone, I. Fung, R.Ruedy, and J. Lerner (1984) Climate sensitivity: analysis of feedback mechanisms. In Hansen, J.E., and T.Takahashi (Eds.) Climate Processes and Climate Sensitivity, Geophys. Monogr. 29, Maurice Ewing Vol. 5,, pp. 130-163, American Geophysical Union, Washington, DC.

Hartmann, D.J., M.O. Ockert-Bell and M.L. Michelsen (1992) The effect of cloud type on Earth's energy balance. J. Climate, 5, 1281-1304.

Harvey, L.D., A two-dimensional ocean model for long-term climate simulations: Stability and coupling to atmospheric and sea ice models. J. Geophys. Res., 97 (C6), 9435-9453.

Hoffert, M.I. (1992) Climate sensitivity, climate feedbacks and policy implications. In Mintzer, I.M., (Ed.) Confronting Climate Change: Risks, Implications and Responses, pp. 33-54, Cambridge University Press, New York.

Hoffert, M.I. (1989a) The ocean in one dimension: upwelling, turbulence, temperature, oxygen, nutrients and carbon. Third International Conference on Analysis and Evaluation of Atmospheric $\mathrm{CO}_{2}$ Data Past and Present. WMO Report 59, World Metorological Organization, Geneva.

Hoffert, M.I. (1989b) Climatic change and ocean bottom water formation: Are we missing something? In M.E. Schlesinger. (Ed.) Climate-Ocean Interaction, pp. 295-318, Kluwer Academic Publishers, Dortrecht, the Netherlands.

Hoffert, M.I. (1988) A world ocean model resolved in depth and latitude. Annual Progress Report to the DOE Carbon Dioxide Climate Program. Earth Systems Group, Department of Applied Science, New york University, New York, NY.

Hoffert, M.I., and C. Covey (1992) Deriving global climace sensitivity from palaeoclimate reconstructions. Nature (to appear in December 10, 1992 issue). 
Hoffert, M.I., A. Frei and V.K. Narayanan (1988) Application of Solar Max Acrim data to analysis of solar-driven climatic variability on earth. Climatic Change, 13, 267-285.

Hoffert, M.I. and B.F. Flannery (1985) Model projections of the timedependent response to increasing carbon dioxide. In MacCracken, M.C. and F.M. Luther (Eds.) Projecting the Climatic Effects of Increasing Carbon Dioxide, DOE/ER-0237, pp.149-190, United States Department of Energy, Washington, DC,

Hoffert, M.I., B.P. Flannery, A.J. Callegari, C.T. Hsieh and W. Wiscombe (1983) Evaporation-limited tropical temperatures as a constraint on climate sensitivity. J. Atmos. Sci., 40, pp. 1659-1668.

Hoffert, M.I., A.J. Callegari and C.-T. Hsieh (1980) The role of deep sea heat storage in the secular response to climatic forcing. J. Geophys. Res., 85 (C11), 6667-6679.

IPCC (1990) Climate Change: The IPCC Scientific Assessment. Houghton, J.T., G.J. Jenkins and J.J. Ephraums (Eds.), Cambridge University Press, New York.

IPCC (1992) Climate Change 1992. Houghton, J.T., B.A. Callander and S.K. Varney (Eds.) Cambridge University Press, New York.

Karl, T.R., G. Kukla, V.N. Razuvayev, M.J. Changery, R.G. Quayle, R.R. Heim, Jr., D.R. Easterling and C.B. Fu (1991) Global warming: Evidence for asmmetrical diurnal temperature change. Geophys. Res. Lett., 18, 22532256.

Keeling, R.F. and S.R. Shertz (1992) Seasonal and interannual variations in atmospheric oxygen and implications for the global carbon cycle. Nature, 358, 723-727.

Kelly, P.M. and T.M.L. Wigley (1992) Solar cycle length, greenhouse forcing and global climate. Nature, 360, 328-330.

Khesghi, H.S., B.P. Flannery and M.I. Hoffert (1991) Marine biota effects on the compositional structure of the world oceans. I. Geophys. Res., 96 (C3), 4957-4969.

Levitus, S. (1982) Climatological Atlas of the World Ocean, NOAA Professional Paper 13, Geophysical Fluid Dynamics Laboratory, Princeton, New Jersey. 
Lindzen, R.S. (1990) Some coolness concerning global warming. Bull. Am. Meter. Soc.., 71, 288-299.

MacCracken, M.C. (1990) CHAMMP Program Overview, UCRL-JC-109518, Oct. 1990, Lawrence Livermore National Laboratory, Livermore, CA.

MacCracken, M.C. (1989) Quantifying the Link Between Change in Radiative Balance and Atmospheric Temperature. Summary of DOE Carbon Dioxide Research Program Workshop held on April 24-25, Comfort Inn, 20260 Goldenrod Lane, Germantown, Maryland.

MacCracken, M.C. (1985) Carbon dioxide and climate change. In MacCracken, M.C., and F.M. Luther (Eds.), Projecting the Climatic Effects of Increasing Carbon Dioxide, DOE/ER-0237, pp. 1-23. US Department of Energy, Carbon Dioxide Research Division, Washington, DC.

MacCracken, M.C., A.D. Hecht, M.I. Budyko and Y.A. Izrael (1990) Prospects for Future Climate: A Special US/USSR Report on Climate and Climate Change. Lewis Publishers, Chelsea, MI.

MacCracken, M.C., and J. Kutzback (1991) Comparing and contrasting Holocene and Eemian warm periods with greenhouse-gas-induced global warming, In Schlesinger, M.E. (Ed.), Greenhouse-Gas-Induced Climatic Change: A Critical Appraisal of Simulations and Observations, pp. 17-19, Elsevier, New York.

Marshall Institute (1989) Scientific Perspectives on the Greenhouse Problem. George C. Marshall Institute, Washington, DC.

Mitchell, J.F.B. (1989) The "greenhouse" effect and climatic change. Rev. Geophys., 27, 115-139.

Monin, A.S. and R.V. Osmidov (1985) Turbulence in the Ocean, edited by H. Tennekes, D. Reidel Publishing Co., Boston, 247 pp.

Moum, J.N. and T.R. Osborn (1986) Mixing in the main thermocline. J. Phys. Oceanogr., 16 (7), 1250-1259.

Newell, R.E. and T.G. Dopplick (1979) Questions concerning the possible influence of anthropogenic $\mathrm{CO}_{2}$ on atmospheric temperature. J. Appl. Meteor., 18, 822-825.

Oort, A.H. '1983) Global Atmospheric Circulation Statistics, 1953-1973, NOAA Professional Pape: 14, Geophysical Fluid Dynamics Laboratory, Princeton, New Jersey. 
Patrinos, A. (1990) Atmospheric Radiation Measurement Program Plan, DOE/ER-0441, Feb. 1990, Atmospheric and Climate Research Division, US Department of Energy, Washington, DC.

Ramanathan, V., R.D. Cess, E.F. Harrison, P. Minnis, B.R. Barkstrom, E. Ahmad and D. Hartmann (1989) Cloud-radiative forcing and climate: Results of the Earth Radiation Budget Experiment. Science, 243, pp. 5763.

Ramanathan, V. and W. Collins (1991) Thermodynamic regulation of ocean warming by cirrus clouds deduced from observations of the $1987 \mathrm{El}$ Niño.Nature, 351, 27-32.

Schlesinger, M.E. and Mitchell, J.F.B. (1985) Model projections of the equilibrium climatic response to increased carbon dioxide. In MacCracken, M.C. and F.M. Luther (Eds.), Projecting the Climatic Effects of Increasing Carbon Dioxide, DOE/ER-0237, pp. 82-147, US Department of Energy, Washington, DC.

Schlesinger, M.E. and X. Jiang (1991) Simple model representation of atmosphere-ocean GCMs and estimation of the timescale of $\mathrm{CO}_{2}$ induced climate change. J. Climate, 3, 1297-1315.

Schlesinger, M.E., X. Jiang and R.J. Charlson (1992) Implications of anthropogenic sulfate for the sensitivity of the climate system. In Rosen, L. and R. Glasser (Eds.) Climate Change and Energy Policy, pp. 75-108, American Institute of Physics, New York.

Schlesinger, M.E. and N. Ramankutty (1992) Implications for global warming of intercycle solar irradiance variations. Nature, 360, 330-333.

Schwartz, S. (1988) Are global cloud albedo and climate controlled by marine phytoplankton? Nature, 336, pp. 441-445.

Somerville, R.C.J. and L.A. Remer (1984) Cloud optical thickness feedbacks in the $\mathrm{CO}_{2}$ climate problem. J. Geophys. Res., 89, pp. 9668-9672.

Street-Perrott, F.A. (1991) General circulation (GCM) modelling of paleoclimates: a critique. The Holocene, 1, 74-80.

Thompson, R. (1971) Topographic Rossby waves at a site north of the Gulf Stream. Deep Sea Res. 18, pp. 1-19.

Washington, W.M., and C.L. Parkingson (1986) An Introduction to ThreeDimensional Climate Modeling, Oxford University Press, New York. 
Wigley, T.M.L. (1989) Possible climatic change due to $\mathrm{SO}_{2}$-derived cloud condensation nuclei. Nature, 339, 365-367.

Wigley, T.M.L. and S.C.B. Raper (1992) Implications for climate and sea level of revised IPCC emissions scenarios. Nature, 357, 293-300. 
TABLE 1 Sensitivity estimates of two paleoclimates

1. Last Glacial Maximum (LGM) cooling 20 ky BP

RADIATIVE FORCING [ $\mathrm{W} \mathrm{m}^{-2}$ ]

\begin{tabular}{|c|c|c|c|c|}
\hline COMPONENT & $\left\langle\Delta Q_{i}\right\rangle$ & $\sigma_{Q i}$ & $\langle\Delta Q\rangle$ & $\sigma_{\mathrm{Q}}=\sqrt{\Sigma \sigma_{Q} \mathrm{i}^{2}}$ \\
\hline SUN & 0.0 & 0.2 & 0.0 & 0.2 \\
\hline ALBEDO & -3.0 & 0.5 & -3.0 & 0.5 \\
\hline GREENHOUSE & -2.8 & 0.3 & -5.8 & 0.6 \\
\hline AEROSOL & -0.9 & 0.7 & -6.7 & 0.9 \\
\hline \multirow{2}{*}{\multicolumn{2}{|c|}{ TEMPERATURE RESPONSE $\left[{ }^{\circ} \mathrm{C}\right]$}} & $\langle\Delta \mathrm{T}\rangle$ & $\sigma$ & \\
\hline & & & -3.0 & 0.6 \\
\hline \multirow{2}{*}{\multicolumn{2}{|c|}{ CLIMATE SENSITIVITY $\left[{ }^{\circ} \mathrm{C}\right]$}} & & $\left\langle\Delta T_{2 x}>\right.$ & $\sigma_{\mathrm{T} 2 \mathrm{x}}$ \\
\hline & & & 2.0 & 0.5 \\
\hline
\end{tabular}

2. Middle Cretaceous Maximum (MCM) warming 100 My BP

RADIATIVE FORCING [W $\mathrm{m}^{-2}$ ]

\begin{tabular}{lrccc} 
COMPONENT & $<\Delta \mathrm{Q}_{\mathrm{i}}>$ & $\sigma_{\mathrm{Qi}}$ & $<\Delta \mathrm{Q}\rangle$ & $\sigma_{\mathrm{Q}}=\sqrt{\Sigma \sigma_{\mathrm{Qi}^{2}}}$ \\
SUN & -1.2 & 0.2 & -1.2 & 0.2 \\
ALBEDO & 5.8 & 0.9 & 4.6 & 0.9 \\
GREENHOUSE & 13.3 & 3.5 & 17.9 & 3.6 \\
TEMPERATURE RESPONSE $\left[{ }^{\circ} \mathrm{C}\right]$ & $<\Delta \mathrm{T}>$ & $\sigma \mathrm{T}$ & \\
& & & 9.0 & 2.0 \\
& & $<\Delta \mathrm{T}_{2 \mathrm{x}}>$ & $\sigma_{\mathrm{T} 2 \mathrm{x}}$ \\
CLIMATE SENSITIVITY $\left[{ }^{\circ} \mathrm{C}\right]$ & & 2.2 & 0.7 \\
\hline
\end{tabular}




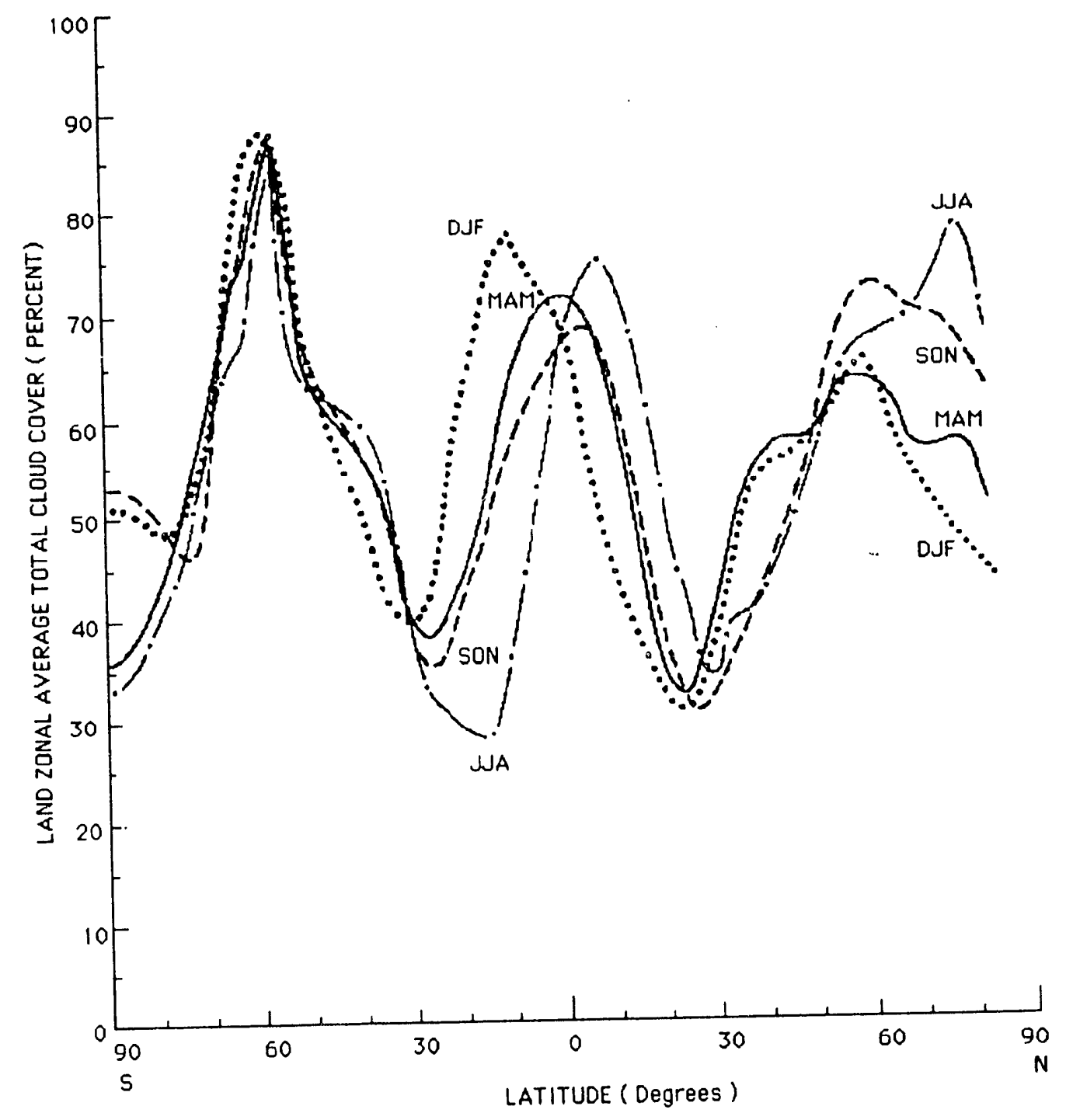

FIG.1 Climatological average (1971-1981) of the present zonal mean land cloud fraction versus latitude for the four seasons from the Hahn et al. (1988) data set of ground-based cloud observations. Although the cloud albedo radiative forcing derived from ERBE and ISCCP satellite climatologies exhibit similar- looking distributions versus latitude, the longwave and net cloud radiative are quite different (Hartmann et al., 1992). What is relevant for determinations of global climate change is the change in cloud radiative forcing induced by a change in global climate. 


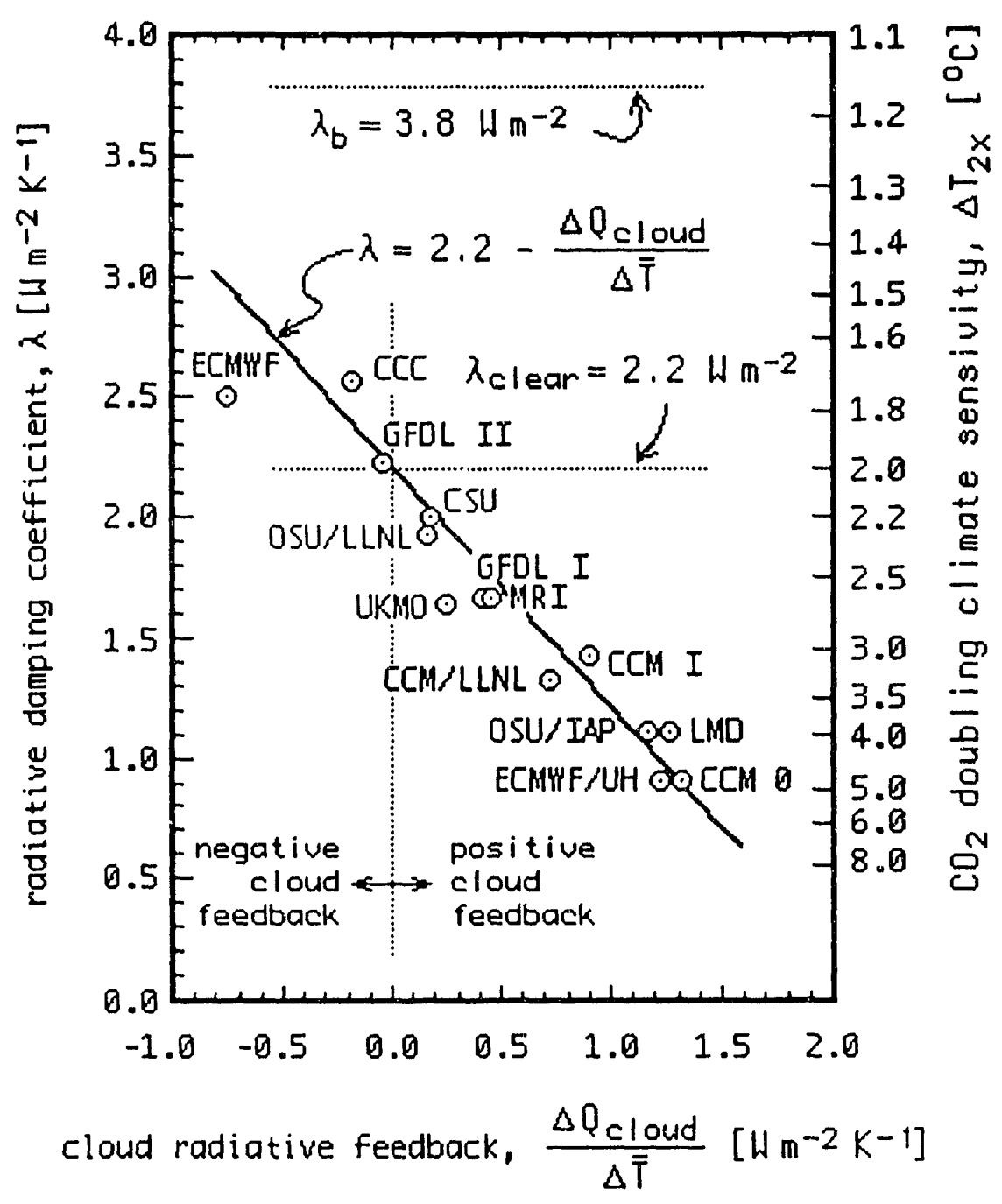

FIG. 2. Radiative damping coefficient and $\mathrm{CO}_{2}$ doubling climate sensitivity versus the cloud radiative feedback parameter of 14 GCMs. The data points are derived from Cess et al. (1989) where the GCM acronyms are defined (but note the different definition of the symbol " $\lambda$ " in Cess et al.). The linear correlation (solid line) implies that a large uncertainty in GCM-derived climate sensitivity arises from differences in the way cloud formation and cloud radiation physics are represented in simplified form in different GCMs. 
Climate sensitivity
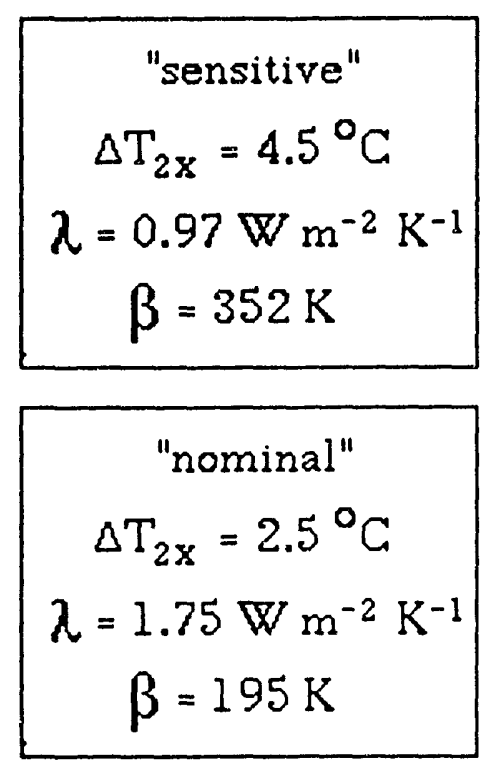

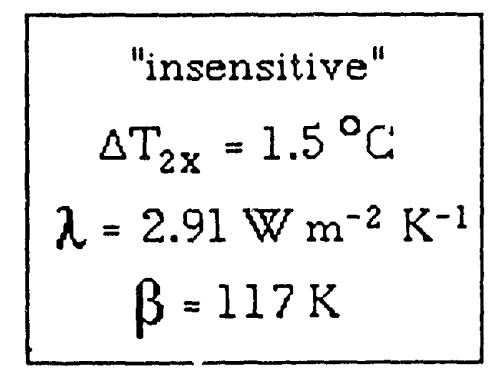

Time-dependent (transient) response
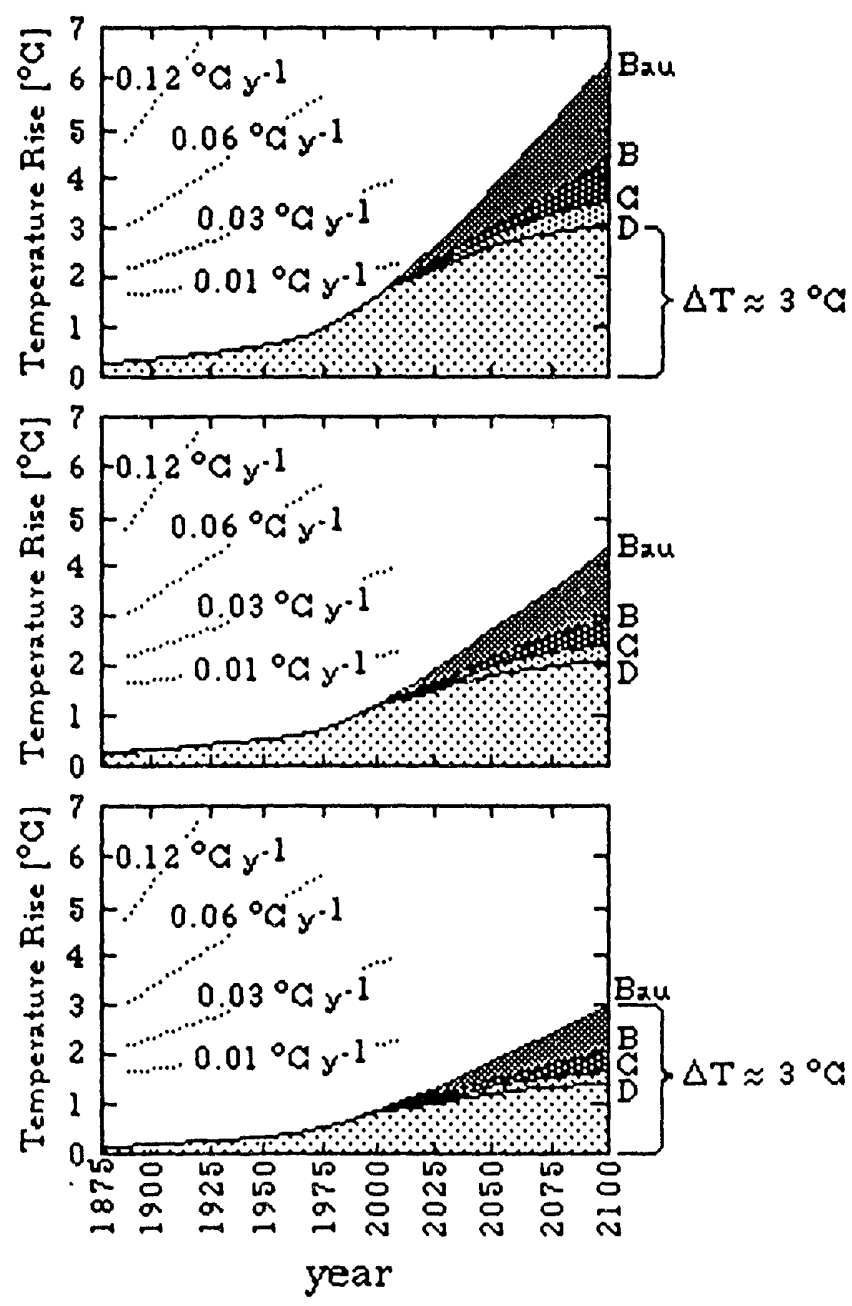

FIG. 3. Twelve predictions of the global mean surface temperature response projected by the Hoffert et al. (1980) upwelling-diffusion ocean climate model to the year 2100 (Hoffert, 1992). For each sensitivity, the right column shows temperature changes for each of four assumptions regarding the future greenhouse gas build-up in the atmosphere. The four assumptions are the IPCC (1990) BaU (Business as Usual), B, C and D radiative forcing scenarios representing progressively stronger greenhouse gas emission controls. 


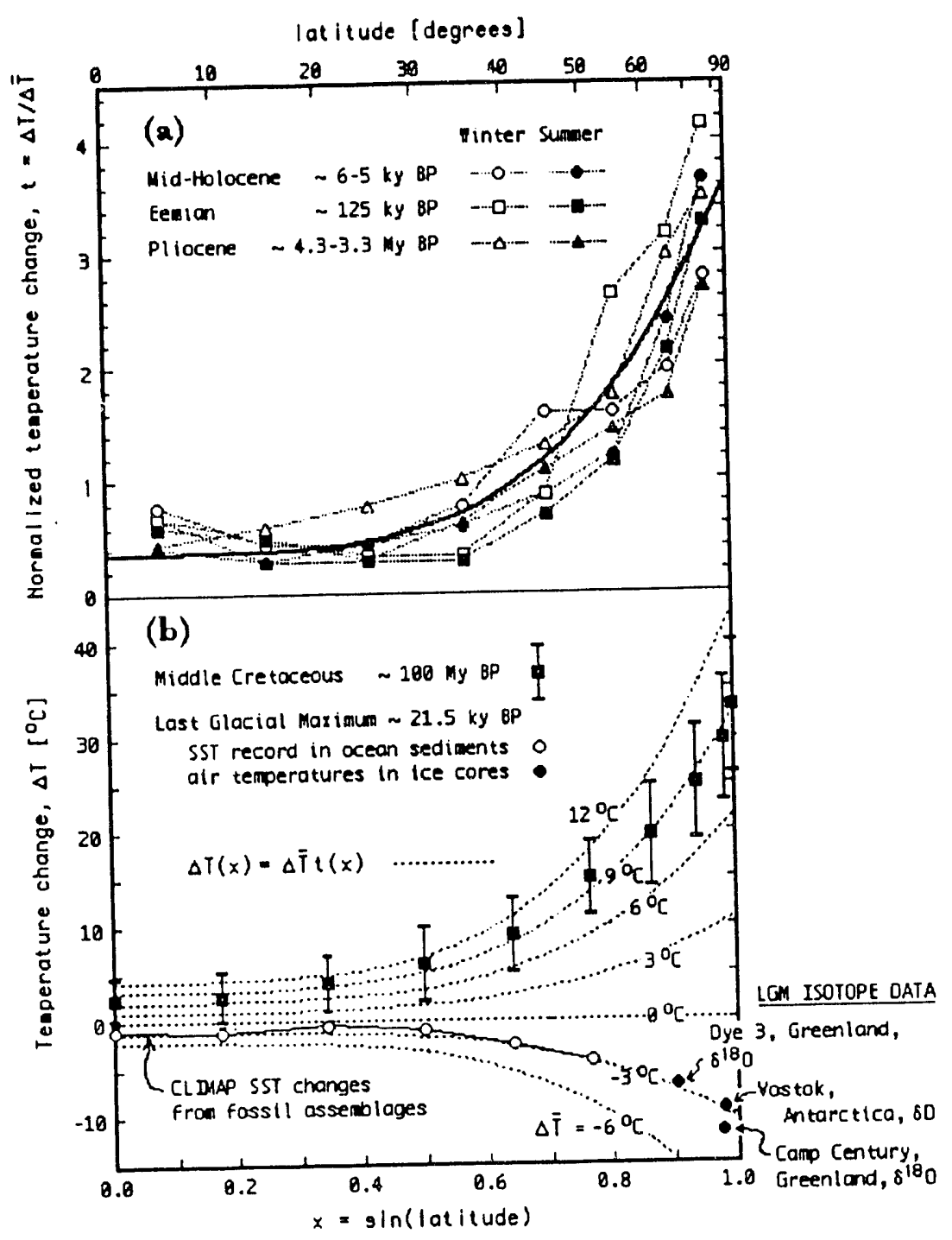

FIG. 4. a, Longitude-averaged surface temperature changes from the present-day climate, normalized by dividing by globally averaged temperature changes. Points connected by dotted lines are Russian paleoreconstructions of the mid-Holocene, Eemian and Pliocene periods. The solid line is a least-squares fit to this data for a forth-order polynomial in the sine of latitude. b, Longitude-averaged surface temperature changes from the present-day climate (average of the northern and southern hemispheres). Points are derived from paleodata for the midCretaceous maximum warming and Last Glacial Maximum cooling (Hoffert and Covey, 1992). Lines show the best-fit normalized temperature curve of FIG. 4a multiplied by the indicated positive and negative global mean temperature changes. Comparison of the lines with a set of points gives the range of global mean temperature change that best fits the data. 

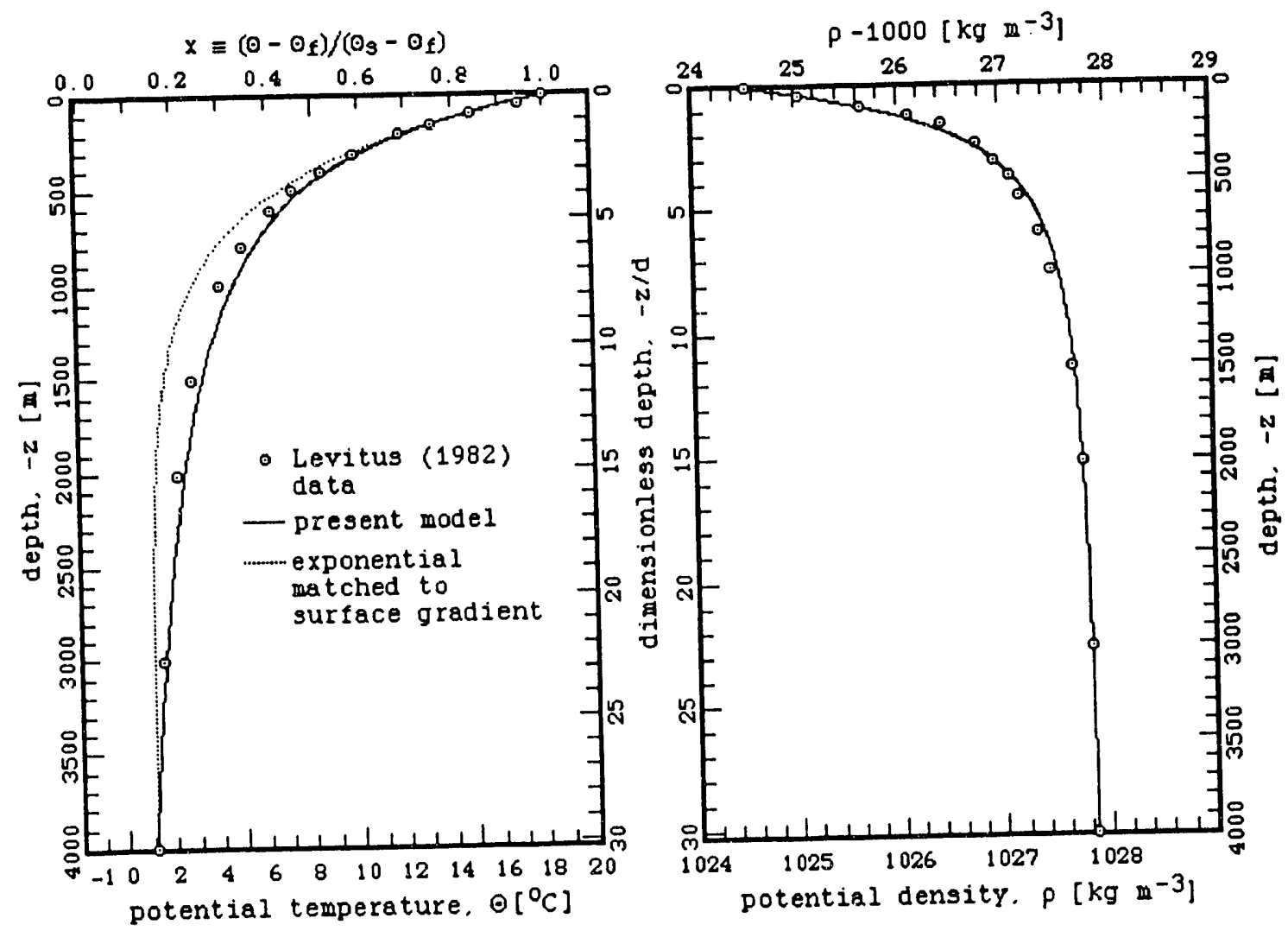

FIG 5. Potential temperature and potential density profiles in the World Ocean comparing the present (variable $\kappa$ ) model to Levitus (1982) horizonally-averaged data. Also shown as a dashed profile in the left panel is the exponential temperature decay with depth to the bottom temperature predicted by a constant $\kappa$ and $w$ model when surface temperature, bottom temperature and surface temperature gradient are all matched to those of the present model. 

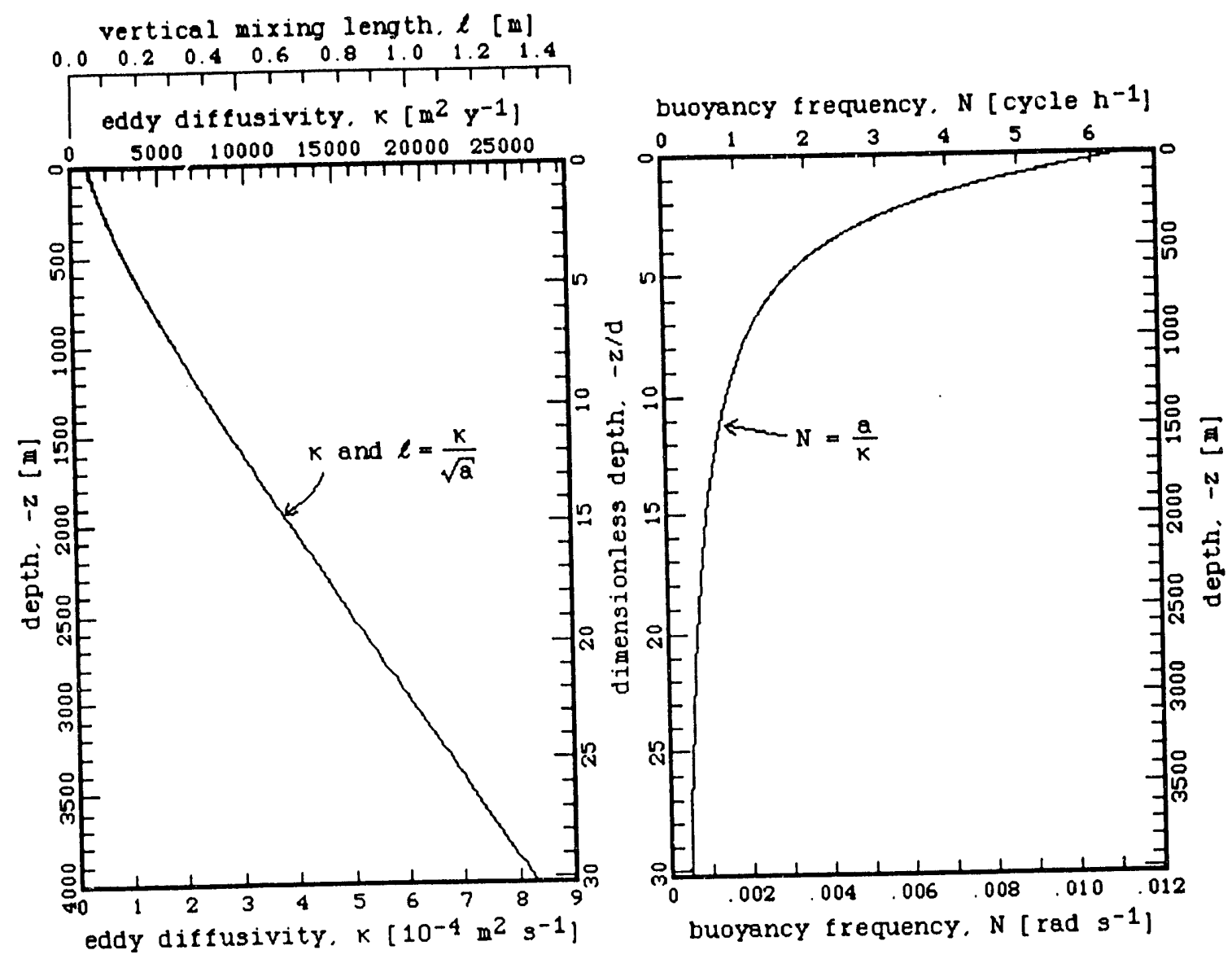

FIG. 6. Vertical eddy diffusivity, mixing length and buoyancy frequency profiles of the present World Ocean. The near-linear increases of eddy diffusivity and mixing length with depth are direct consequences of their inverse scaling with buoyancy frequency in the model. While these quantities vary by a factor of $\sim 25$ over the entire water column, the value of eddy diffusivity at the 500 meter depth, $\mathrm{k} \sim 10^{-4} \mathrm{~m}^{2} \mathrm{~s}^{-1}$, is in the range generally cited in tracer studies and constant-transport-coefficient upwelling-diffusion models. However, the very large diffusivity of the deep sea means changes in bottom temperature and upwelling exert much stronger leverage on profile shapes than previously considered. 

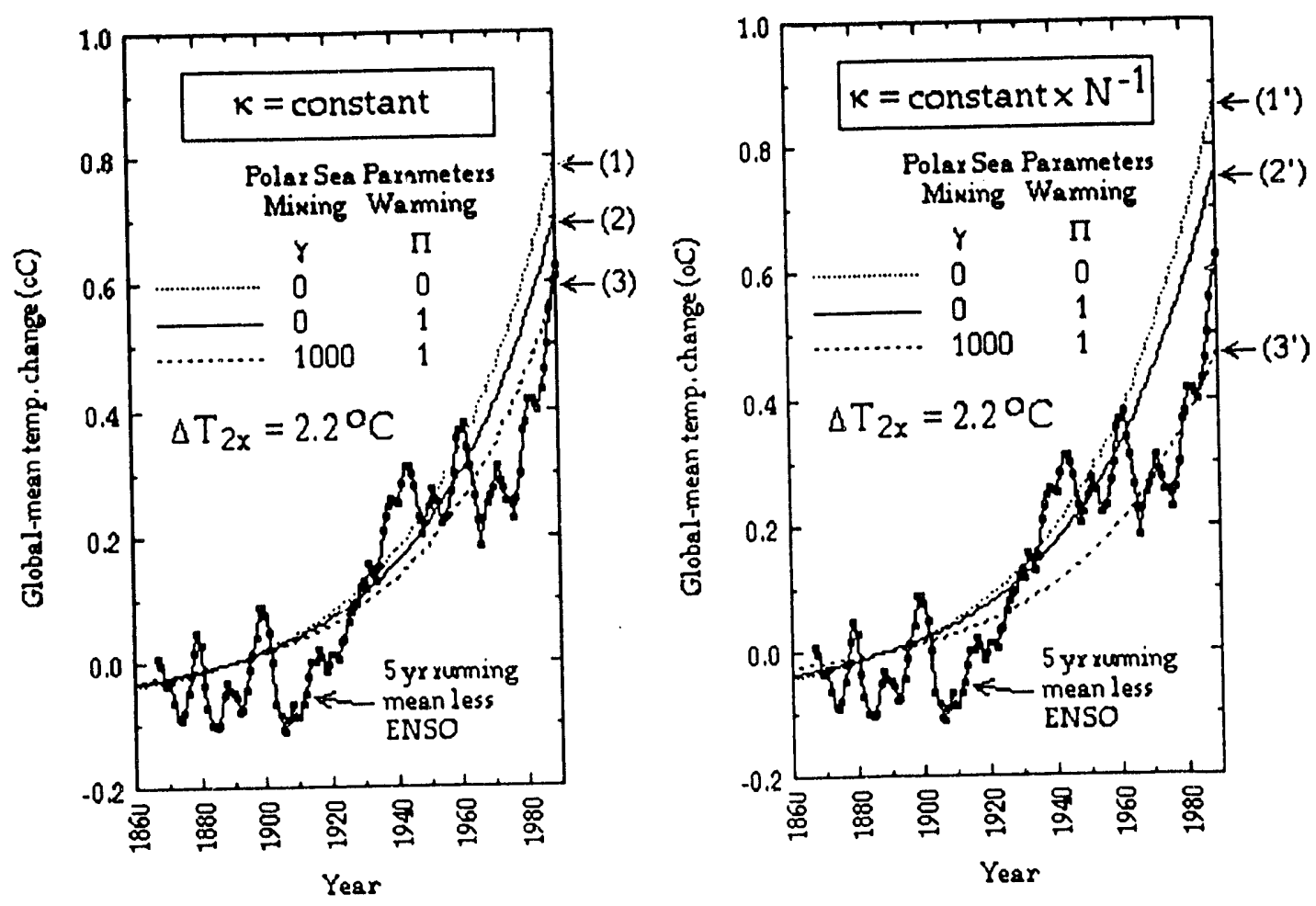

FIG. 7. Six NYU ocean/climate model runs radiatively forced by historical IPCC (1990) greenhouse gas build-up compared with the instrumental surface temperature record of the past hundred years: (1) constant eddy diffusivity, no polar sea warming or overturn; (2) constant eddy diffusivity, moderate polar warming but no ovcrturn (IPCC assumption); (3) constant eddy diffusivity, moderate polar warming with strong overturn mixing in the polar sea; (1') stratification-dependent eddy diffusivity, no polar sea warming or overturn; (2') stratificationdependent eddy diffusivity, moderate polar warming, but no overturn; and (3') stratificationdependent eddy diffusivity, moderate polar warming with strong overturn mixing in the polar sea 

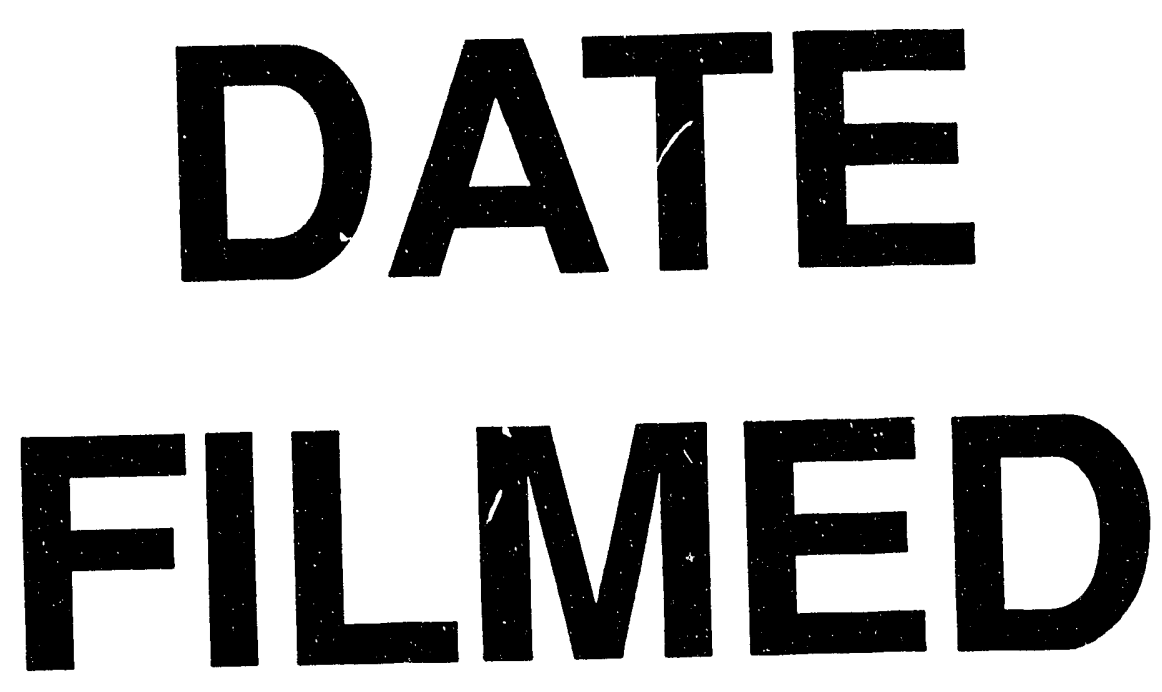

$8 / 4 / 93$
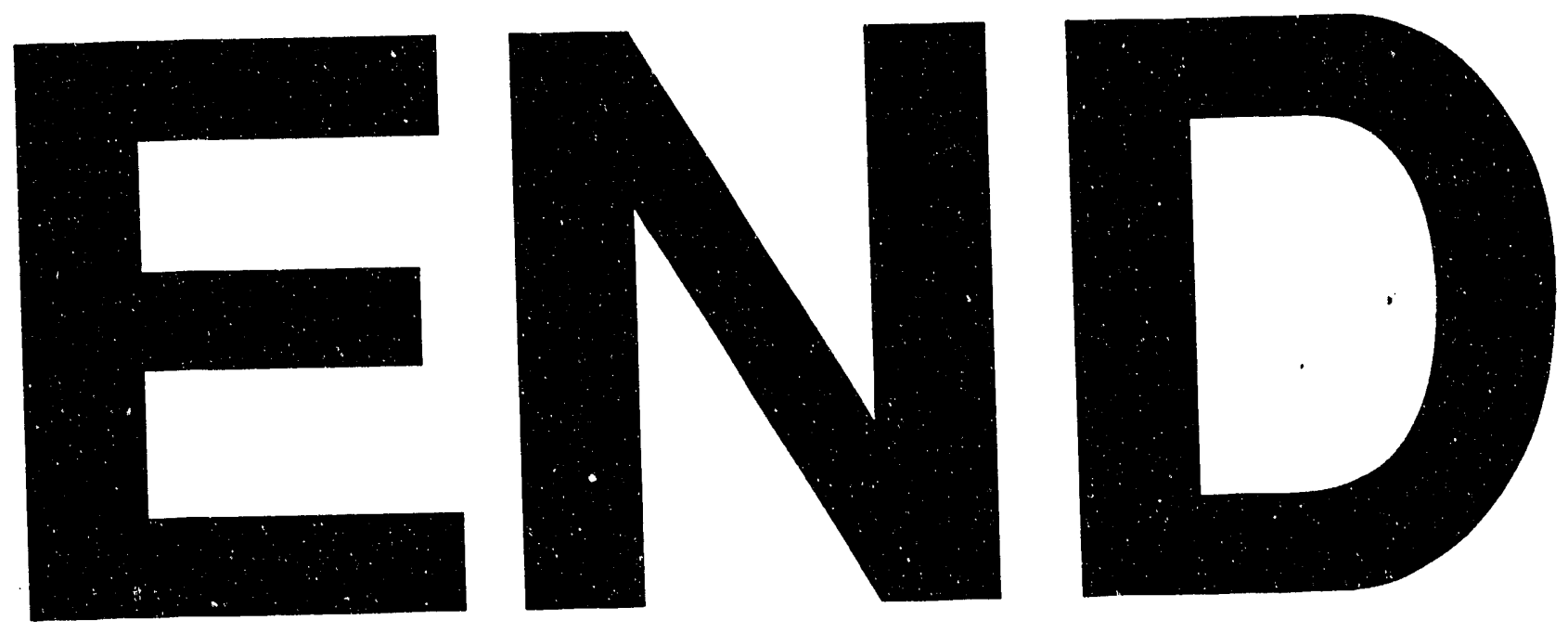


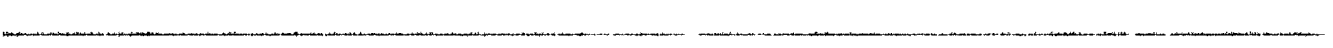

